\title{
ANALISIS DISKRIMINAN UNTUK MENENTUKAN STATUS KETERTINGGALAN DESA DI PROVINSI JAWA TENGAH TAHUN 2014
}

\author{
Bryandika Eri Pradana1*, Muhamad Fathul Muin² \\ ${ }^{1}$ Badan Pusat Statistik, Indonesia \\ 2Badan Pusat Statistik Provinsi Papua, Indonesia \\ *Email korespondensi: bryandikaeripra@gmail.com
}

\begin{abstract}
Abstrak
Ketimpangan pembangunan antar wilayah dapat menimbulkan terbentuknya desa tertingal Jawa Tengah sebagai salah satu provinsi di Pulau Jawa yang telah melakukan berbagai proses pembangunan, masih memiliki masalah ketimpangan dan ketertinggalan pada wilayah pedesaan. Salah satu langkah yang dapat dilakukan untuk menentukan kategori kertinggalan desa tersebut melalui pembentukan fungsi diskriminan. Variabel yang digunakan dalam fungsi tersebut sebanyak 17 variabel dan hanya 3 variabel yang signifikan dan berarti dalam pembentukan model. Ketiga variabel tersebut adalah letak desa terhadap hutan, penerangan jalan, dan penggunaan bahan bakar memasak. Fungsi diskriminan yang terbentuk mampu memprediksi pengelompokan desa tertinggal dan desa tidak tertinggal sebesar 84,1 persen.

Kata Kunci: analisis diskriminan, prediksi spasial, wilayah tertinggal.
\end{abstract}

\begin{abstract}
An Inequality in development of the regions can lead to formed the remote villages. Central Java as one of the provinces in Java has carried out the various of development processes, but still has a problem of inequality and underdevelopment in rural areas. Something can be taken to determine the category of backward rural using the discriminant model. The variables used in the function are 17 variables and only 3 variables are significant and meaningful in the model. All three variables used are: the village location to the forest, street lighting, and the cooking fuel usage. The resulting discriminant model can accurately predict the grouping of underdeveloped villages and developed villages by 84.1 percent.
\end{abstract}

Keywords: discriminant analysis, spatial prediction, underdeveloped region.

\section{PENDAHULUAN}

Sebagai negara berkembang, Indonesia tengah dihadapkan dengan berbagai persoalan pembangunan (Sumodinigrat, 2007), diantaranya terkait ketidakmerataan pembangunan. Dampak riil dari ketidakmerataan tersebut adalah munculnya wilayah tertinggal. Akibatnya, wilayah tersebut harus menghadapi keterbatasan aksesibilitas terhadap infrastruktur pelayanan dasar (Bappenas, 2014). Di Indonesia pembangunan masih terpusat di bagian barat khususnya di Pulau Jawa (Fauzia, 2019). Kendatipun demikian, Pulau Jawa tetap memiliki permasalahan pembangunan. Salah satu provinsi dengan persentase penduduk miskin tertinggi berdasarkan Survei Sosial Ekonomi Nasional (Susenas) adalah Jawa Tengah (Badan Pusat Statistik, 2019). Indeks ketimpangan antar wilayah di provinsi tersebut relatif tinggi yaitu sebesar 0,67 pada tahun 2011 dan sebesar 0,64 pada tahun 2014 (Badan Pusat Statistik Kabupaten Pekalongan, 2019). Walaupun terjadi tren penurunan, namun nilai indeks tersebut masih lebih besar dari 0,5 yang artinya ketimpangan antar wilayah di Jawa Tengah masih tinggi.

Umumnya, desa tertinggal diidentikkan dengan kondisi penduduknya yang tergolong miskin (Trinanda \& Santoso, 2013). Diantara penyebabnya adalah kondisi geografis desa yang terisolasi dari pusat pembangunan serta rendahnya kualitas sumber daya manusia yang dimiliki oleh penduduk tersebut (Mubyarto, 1994). Namun demikian, identifikasi tersebut bisa saja berbeda untuk wilayah yang berbeda. Merujuk kepada klasifikasi Indeks Pembangunan Desa (IPD) tahun 2014, di Jawa Tengah tercatat sebanyak 1,57 persen desa masih berada dalam ketegori desa tertinggal, 89,91 persen desa berada dalam kategori desa berkembang, dan 8,52 persen desa berada dalam kategori desa mandiri (Badan Pusat Statistik, Indeks Pembangunan Desa 2014, 2015). Walaupun jumlah persentase desa tertinggal dibawah 2 persen, namun jumlah 
penduduk miskin di Jawa Tengah mencapai 14,46 persen. Ketidak sinkronan kedua data tersebut menjadi dilematis, terlebih dalam hal akurasi penentuan klasifikasi wilayah (desa) tertinggal dan tidak tertinggal.

Berbagai penelitian telah dilakukan sebelumnya, diantaranya oleh Zamhari (2015) tentang determinan kemiskinan di Jawa Timur. Hasil studi menunjukkan bahwa keberadaan fasilitas telekomunikasi dan status wilayah berpengaruh terhadap determinan kemiskinan di Jawa Timur. Selain itu penelitian yang dilakukan oleh Nopriansyah, dkk (2015) juga menujukkan bahwa klasifikasi desa/kota juga berpengaruh terhadap kemiskinan di Provinsi jambi. Penelitian lain juga menunjukkan bahwa variasi kemiskinan antar daerah dapat dipengaruhi oleh faktor penguasaan asset (Giyarsih, 2014) dan keberadaan infastruktur (Usman, Sinaga, \& Siregar, 2006). Oleh karena itu, dalam penelitian ini diharapkan terbentuk model klasifikasi baru dengan variabel pembeda yang efektif, khususnya di Jawa Tengah. Selain itu, penelitian ini juga memiliki tujuan untuk memperoleh hasil klasifikasi desa tertinggal dan tidak tertinggal yang tidak berbeda secara signifikan terhadap persentase penduduk miskin versi hasil survei Susenas.

\section{TINJAUAN PUSTAKA DAN PERUMUSAN HIPOTESIS}

\section{Pembangunan dan Wilayah}

Pembangunan merupakan proses transformasi ekonomi, sosial dan budaya melalui kebijakan dan strategi untuk menuju ke arah yang lebih baik (Tikson, 2005). Selain itu, pembangunan juga dapat diartikan sebagai pertumbuhan secara kualitatif maupun kuantitatif terhadap kemampuan suatu kelompok (Chalid, 2015). Setiap pembangunan yang dilakukan tidak dapat terlepas dari aspek kewilayahan. Sehingga konsep kewilayahan diperlukan sebagai pendekatan agar pembangunan yang berimbang antar sektor dapat dicapai (Rosalina, 2008).

Menurut BPPT (2002) tingkat pembangunan antar wilayah yang berbeda menyebabkan munculnya karakteristik yang berbeda pada wilayah tersebut. Sehingga perbedaan tersebut menyebabkan adanya 5 klasifikasi wilayah, yaitu: wilayah maju, wilayah netral, wilayah sedang, wilayah kurang berkembang, dan wilayah tidak berkembang.

\section{Wilayah Tertinggal}

Wilayah tertinggal merupakan wilayah yang kondisinya relatif tertinggal dibandingkan wilayah lainnya (Ratnadila, 2018). Kemajuan ataupun ketertinggalan suatu wilayah dapat dicerminkan oleh tingkat kemiskinan suatu wilayah (desa) yang dapat diwakili oleh variabel status ketertinggalan desa. Selain itu, menurut Badan Perencanaan Pembangunan Nasional (Muhtar \& dkk, 2011) suatu wilayah dapat dikategorikan tertinggal karena secara geografis relatif sulit dijangkau, tidak memiliki potensi sumber daya alam, kualitas sumber daya manusia rendah, keterbatasan sarana dan prasarana, serta sering terjadi bencana alam dan konflik sosial. Selain itu kelembagaan yang kurang baik juga turut mempengaruhi masalah ketertinggalan karena kesalahan dalam penentuan prioritas pembangunan (Rosalina, 2008).

Adapun kriteria untuk menentukan wilayah tertinggal menurut Kementerian Desa, Pembangunan Daerah Tertinggal dan Transmigrasi - KDPDTT (2016) teridiri atas: (1) kriteria perekonomian: jumlah penduduk miskin dan pengeluaran per kapita, (2) kriteria sumber daya manusia: angka harapan hidup, rata-rata lama sekolah, angka melek huruf, (3) kriteria kemampuan keuangan daerah, (4) kriteria infrastruktur/sarana prasarana: jalan aspal/beton, jalan diperkeras, jalan tanah, jalan lainnya, pasar tanpa bangunan, fasilitas kesehatan, jumlah dokter, fasilitas pendidikan, persentase rumah tangga pengguna listrik, persentase rumah tangga pengguna telepon, persentase rumah tangga pengguna air bersih, (5) kriteria aksesibilitas: jarak ke ibukota kabupaten, akses ke pelayanan kesehatan, akses ke pelayanan pendidikan dasar, dan (6) kriteria karakteristik daerah: gempa bumi, tanah longsor, banjir, bencana lainnya, kawasan hutan lindung, berlahan kritis, desa konflik. 


\section{METODE PENELITIAN}

\section{Jenis Penelitian}

Kajian yang dilakukan dalam penelitian ini bersifat kuantitatif deskriptif. Data kuantitatif yang digunakan merupakan data pada level desa. Adapun metode statistik deskriptif untuk menginterpretasikan hasil penelitian adalah analisis diskriminan.

\section{Ruang Lingkup Penelitian}

Unit analisis penelitian ini adalah 227 sampel desa di Jawa Tengah pada tahun 2014 yang diambil secara stratified systematic random sampling. Adapun sumber data yang digunakan adalah data sekunder dari pendataan Potensi Desa (PODES) 2014 Provinsi Jawa Tengah. Desa yang tercakup pada PODES 2014 adalah desa yang memenuhi tiga syarat yaitu: memiliki wilayah dengan batas yang jelas, penduduk menetap di wilayah desa serta terdapat pemerintahan desa.

\section{Analisis Diskriminan}

Analisis diskriminan merupakan teknik statistik multivariat yang berfungsi untuk memisahkan set objek yang berbeda dan mengalokasikannya ke dalam grup tertentu (Johnson \& Wichern, 2007). Implementasinya dalam penelitian ini untuk mengklasifikasikan suatu desa kedalam kelompok desa tertinggal dan desa tidak tertinggal. Beberapa asumsi yang harus dipenuhi dalam analisis tersebut yaitu data berdistribusi multivariat normal dan setiap populasi mempunyai matriks kovarian yang sama (Supranto, 2004).

Secara umum, fungsi diskriminan dapat dituliskan sebagai berikut (Pane, Topowijono, \& Husaini, 2015):

Keterangan:

$$
\widehat{Y}=a+b_{1} X_{1}+b_{2} X_{2}+\cdots+b_{n} X_{n}
$$

$\widehat{Y} \quad$ : nilai diskriminan

a : konstanta

$\mathrm{b}_{1, \ldots, \mathrm{n}} \quad$ : koefisien ke $1,2, \ldots, \mathrm{n}$

$\mathrm{X}_{1, \ldots, \mathrm{n}} \quad$ : variabel bebas ke $1,2, \ldots, \mathrm{n}$

Adapun tahapan pelaksanaan analisis diskriminan yaitu sebagai berikut: (1) menguji asumsi perbedaan vektor rataan antar kelompok, (2) menguji asumsi keseragaman matriks kovarians, (3) memilih variabel yang masuk ke dalam fungsi diskriminan, (4) mendapat fungsi diskriminan, dan (5) melihat akurasi fungsi diskriminan dengan menghitung kesalahan klasifikasi.

\section{Evaluasi fungsi klasifikasi}

Untuk mengevaluasi fungsi klasifikasi yang terbentuk digunakan ukuran Apparent Error Rate(APER). Ukuran tersebut untuk mengetahui observasi yang misklasifikasi dengan menunjukkan nilai asli di bandingkan dengan keanggotaan dari kelompok yang diprediksi.

Tabel 1. Klasifikasi kelompok

\begin{tabular}{ccccc}
\hline & \multicolumn{4}{c}{ Nilai Prediksi } \\
\cline { 2 - 5 } & \multicolumn{3}{c}{$\hat{\pi}_{1}$} & $\hat{\pi}_{2}$ \\
\hline Nilai & $\pi_{1}$ & $n_{1 c}$ & $n_{1 m}=n_{1}-n_{1 c}$ & $n_{1}$ \\
\cline { 2 - 5 } sebenarnya & $\pi_{2}$ & $n_{2 m}=n_{2}-n_{2 c}$ & $n_{2 c}$ & $n_{2}$ \\
\hline
\end{tabular}

\section{Keterangan:}

$n_{1 c} \quad$ : jumlah dari $\pi_{1}$ item yang tepat dikelompokkan pada $\hat{\pi}_{1}$ item

$n_{1 m}$ : jumlah dari $\pi_{1}$ item yang salah dikelompokkan pada $\hat{\pi}_{2}$ item

$n_{2 c} \quad$ : jumlah dari $\pi_{2}$ item yang tepat dikelompokkan pada $\hat{\pi}_{2}$ item

$n_{2 m} \quad$ : jumlah dari $\pi_{2}$ item yang salah dikelompokkan pada $\hat{\pi}_{1}$ item

Sehingga rumus apparent error rate adalah sebagai berikut

$$
A P E R=\frac{n_{1 m}+n_{2 m}}{n_{1}+n_{2}} \times 100 \%
$$

Adapun untuk menghitung ketepatan pengelompokan item digunakan nilai hit ratio dengan formulasi sebagai berikut:

$$
\text { Hit ratio }=(1-A P E R) \times 100 \%
$$




\section{Variabel Dependen}

Variabel dependen yang digunakan untuk menklasifikasikan desa kedalam kelompok desa tertinggal dan desa tidak tertinggal adalah pengelolaan lingkungan. Rincian variabel proxy untuk mengukur pengelolaan lingkungan tersebut adalah sebagai berikut.

Tabel 2. Variabel Penyusun Klasifikasi Awal Desa

\begin{tabular}{|c|c|c|}
\hline Variabel & Jenis & Kategori \\
\hline \multirow{2}{*}{$\begin{array}{l}\text { Tempat buang air } \\
\text { besar sebagian besar } \\
\text { keluarga }\end{array}$} & $\begin{array}{l}\text { 1: Jamban sendiri } \\
\text { 2: Jamban bersama }\end{array}$ & Tidak tertinggal \\
\hline & $\begin{array}{l}\text { 3: Jamban umum } \\
\text { 4: Bukan jamban }\end{array}$ & Tertinggal \\
\hline \multirow{2}{*}{$\begin{array}{l}\text { Tempat } \quad \text { buang } \\
\text { sampah sebagian } \\
\text { besar keluarga }\end{array}$} & $\begin{array}{l}\text { 1: Tempat sampah, kemudian diangkut } \\
\text { 2: Dalam lubang/dibakar }\end{array}$ & Tidak tertinggal \\
\hline & $\begin{array}{l}\text { 3: Sungai/saluran irigasi/danau/laut } \\
\text { 4: Drainase (got/selokan) } \\
\text { 5: Lainnya }\end{array}$ & Tertinggal \\
\hline \multirow{2}{*}{$\begin{array}{l}\text { Tempat } \\
\text { penampungan } \\
\text { sampah sementara }\end{array}$} & 1: Ada & Tidak tertinggal \\
\hline & 2: Tidak ada & Tertinggal \\
\hline \multirow{2}{*}{$\begin{array}{lr}\text { Tempat/saluran } \\
\text { pembuangan } & \text { limbah } \\
\text { cair/air } & \text { kotor } \\
\text { sebagian } & \text { besar } \\
\text { keluarga } & \end{array}$} & $\begin{array}{l}\text { 1: Lubang resapan } \\
\text { 2: Drainase (got/selokan) }\end{array}$ & Tidak tertinggal \\
\hline & $\begin{array}{l}\text { 3: Sungai/saluran irigasi/danau/laut } \\
\text { 4: Dalam lubang/tanah terbuka } \\
\text { 5: Lainnya }\end{array}$ & Tertinggal \\
\hline \multirow[t]{2}{*}{$\begin{array}{l}\text { Sumber air untuk } \\
\text { minum sebagian } \\
\text { besar keluarga }\end{array}$} & $\begin{array}{l}\text { 1: Air kemasan } \\
\text { 2: Ledeng dengan } \\
\text { meteran(PAM/PDAM) } \\
\text { 3: Ledeng tanpa meteran } \\
\text { 4: Sumur bor/pompa } \\
\text { 5: Sumur }\end{array}$ & Tidak tertinggal \\
\hline & $\begin{array}{l}\text { 6: Mata air } \\
\text { 7: Sungai/danau/kolam } \\
\text { 8: Air hujan } \\
\text { 9: Lainnya }\end{array}$ & Tertinggal \\
\hline \multirow{2}{*}{$\begin{array}{l}\text { Sumber air untuk } \\
\text { mandi/cuci sebagian } \\
\text { besar keluarga }\end{array}$} & $\begin{array}{l}\text { 1: Ledeng } \\
\text { meteran(PAM/PDAM) } \\
\text { 2: Ledeng tanpa meteran } \\
\text { 3: Sumur bor/pompa } \\
\text { 4: Sumur }\end{array}$ & Tidak tertinggal \\
\hline & $\begin{array}{l}\text { 5: Mata air } \\
\text { 6: Sungai/danau/kolam } \\
\text { 7: Air hujan } \\
\text { 8: Lainnya }\end{array}$ & Tertinggal \\
\hline
\end{tabular}

Skor terhadap masing-masing variabel adalah bernilai 1 untuk kategori tidak tertinggal dan skor 0 untuk kategori tertinggal. Hasil akhirnya, setiap desa akan memiliki skor total $0-6$. Adapun pengkategorian suatu desa termasuk tertinggal atau tidak tertinggal menggunakan cutting point sebesar 3. 
Tabel 3. Pengkategorian Desa dalam Pengelolaan Lingkungan

\begin{tabular}{ccc}
\hline No & Kriteria & Pengelolaan lingkungan \\
\hline 1. & Skor total $\leq 3$ & Tidak tertinggal \\
\hline 2. & Skor total $>3$ & Tertinggal \\
\hline
\end{tabular}

\section{Variabel Pembeda}

Variabel pembeda yang digunakan sebagai penentu klasifikasi desa tertinggal dan desa tidak tertinggal berdasarkan 17 variabel. Rincian variabel proxy yang digunakan adalah sebagai berikut.

Tabel 4. Kategorisasi Variabel Pembeda yang Digunakan dalam Penelitian

\begin{tabular}{|c|c|c|}
\hline Variabel & Nama Variabel & Kategori \\
\hline $\mathrm{X}_{1}$ & Letak desa terhadap hutan & $\begin{array}{l}\text { 0: di dalam } \\
\text { 1: di sekitar/tepi } \\
\text { 2: di luar }\end{array}$ \\
\hline $\mathrm{X}_{2}$ & Jarak ke kantor camat & - \\
\hline $\mathrm{X}_{3}$ & Jarak ke kantor bupati & - \\
\hline $\mathrm{X}_{4}$ & $\begin{array}{l}\text { Sumber penghasilan utama sebagian } \\
\text { besar penduduk desa }\end{array}$ & $\begin{array}{l}\text { 0: pertanian } \\
\text { 1: selain pertanian }\end{array}$ \\
\hline $\mathrm{X}_{5}$ & Persentase keluarga pengguna listrik PLN & - \\
\hline $\mathrm{X}_{6}$ & $\begin{array}{l}\text { Bahan bakar memasak sebagian besar } \\
\text { keluarga }\end{array}$ & $\begin{array}{l}\text { 0: gas kota, LPG } \\
\text { 1: minyak tanah, kayu } \\
\text { bakar, lainnya }\end{array}$ \\
\hline $\mathrm{X}_{7}$ & Keberadaan angkutan umum & $\begin{array}{l}0: \text { tidak ada } \\
\text { 1: ada, tanpa trayek tetap } \\
\text { 2: ada, dengan trayek tetap }\end{array}$ \\
\hline $\mathrm{X}_{8}$ & Keberadaan kelompok pertokoan & $\begin{array}{l}0: \text { tidak ada } \\
1: \text { ada }\end{array}$ \\
\hline $\mathrm{X}_{9}$ & $\begin{array}{l}\text { Jumlah bangunan pasar permanen/semi } \\
\text { permanen }\end{array}$ & - \\
\hline $\mathrm{X}_{10}$ & Jumlah sarana pendidikan (SMP/MTs) & - \\
\hline $\mathrm{X}_{11}$ & Jumlah sarana kesehatan & - \\
\hline $\mathrm{X}_{12}$ & $\begin{array}{l}\text { Jalan dapat dilalui kendaraan bermotor } \\
\text { roda } 4 \text { atau lebih }\end{array}$ & $\begin{array}{l}0: \text { tidak dapat dilalui } \\
\text { sepanjang tahun } \\
\text { 1: selama musim kemarau } \\
\text { 2: sepanjang tahun kecuali } \\
\text { saat tertentu } \\
\text { 3: sepanjang tahun }\end{array}$ \\
\hline $\mathrm{X}_{13}$ & Jenis penerangan di jalan utama desa & $\begin{array}{l}\text { 0: diusahakan oleh non } \\
\text { pemerintah } \\
\text { 1: diusahakan } \\
\text { pemerintah }\end{array}$ \\
\hline $\mathrm{X}_{14}$ & Keberadaan Bank & $\begin{array}{l}0 \text { : tidak ada } \\
1 \text { : ada }\end{array}$ \\
\hline $\mathrm{X}_{15}$ & Jumlah Koperasi Unit Desa (KUD) & - \\
\hline $\mathrm{X}_{16}$ & Fasilitas Kredit diterima warga & $\begin{array}{l}0 \text { : tidak ada } \\
\text { 1: ada }\end{array}$ \\
\hline $\mathrm{X}_{17}$ & Kegiatan Gotong Royong & $\begin{array}{l}0 . \text { tidak ada } \\
\text { 1. ada }\end{array}$ \\
\hline
\end{tabular}

\section{HASIL DAN PEMBAHASAN}

Berdasarkan hasil klasifikasi awal, dari 227 desa yang ada, sebanyak 41 desa tergolong tertinggal dan 186 desa tidak tertinggal. Persentase ketertinggalan desa tersebut linear terhadap 
deskripsi data pada masing-masing faktor, yaitu: faktor alam/lingkungan, faktor sosial ekonomi, faktor sarana prasarana dan akses, dan faktor kelembagaan.

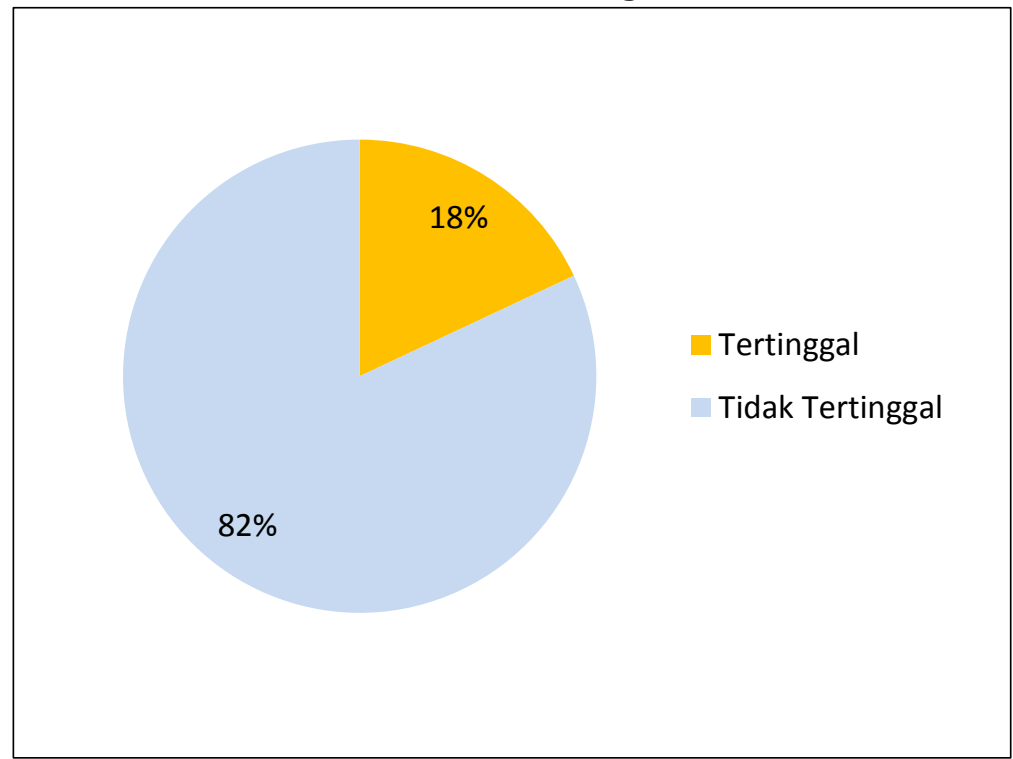

Gambar 1. Klasifikasi Awal Desa Tertinggal di Jawa Tengah Tahun 2014

Selanjutnya, untuk menghasilkan fungsi diskriminan yang baik perlu memenuhi asumsi dasar yaitu normalitas multivariat serta perbedaan secara nyata antar dua kelompok. Dalam hal normalitas, jumlah sampel yang digunakan sebanyak 227 sampel desa sehingga dapat dikatakan ukuran sampel mencukupi untuk memenuhi asumsi ormlitas (Gujarati \& Porter, 2008). Adapun pembuktikan terhadap perbedaan antar kelompok, dilakukan uji $\mathrm{F}$ dengan statistik uji $\mathrm{T}$ Hotelling seperti pada tabel 5. Kesimpulannya bahwa kelompok desa tertinggal dan tidak tertinggal berbeda secara signifikan. Oleh karena itu, berdasarkan kesimpulan terhadap kedua asumsi tersebut maka fungsi diskriminan dapat dibentuk.

Tabel 5. Hasil Pengujian Perbedaan Rata-Rata Kelompok

\begin{tabular}{cccccc}
\hline Efek & Nilai & $\mathrm{F}$ & Hipotesis df & Eror df & Sig. \\
\hline Intersep & 934,748 & 11491,900 & 17,000 & 209,000 & 0,000 \\
\hline Klasifikasi Desa & 0,247 & 3,036 & 17,000 & 209,000 & 0,000 \\
\hline
\end{tabular}

Selanjutnya, dilakukan uji kesamaan varians untuk memenuhi asumsi bahwa matriks varians kedua kelompok. Berdasarkan tabel 6 didapatkan bahwa varians kelompok desa dengan pengolahan lingkungan hidup tidak tertinggal dan tertinggal tidak sama. Karena varians kedua kelompok berbeda, maka diperlukan varians gabungan (Spooled) agar fungsi diskriminan dapat dibentuk.

Tabel 6. Hasil pengujian Kesamaan Varians

\begin{tabular}{|c|c|c|}
\hline \multicolumn{2}{|c|}{ Keterangan } & Nilai \\
\hline \multicolumn{2}{|c|}{ Box's M } & 21,566 \\
\hline \multirow{4}{*}{$\mathrm{F}$} & Approx. & 3,493 \\
\hline & df1 & 6 \\
\hline & df2 & 30023,069 \\
\hline & Sig. & 0,02 \\
\hline
\end{tabular}

Hasil pengujian signifikansi terhadap 17 variabel sebagaimana pada tabel 7, diperoleh empat variabel yang signifikan $(p$-value $<0,05)$ untuk membedakan suatu desa tergolong desa tertinggal dan desa tidak tertinggal. Keempat variabel tersebut meliputi: lokasi desa terhadap 
hutan, bahan bakar memasak, keberadaan sarana kesehatan, dan jenis penerangan jalan. Adapun 13 variabel lainnya tidak signifikan dan perlu dikeluarkan dari proses pembentukan model.

Tabel 7. Hasil Tests of Equality of Group Means

\begin{tabular}{lccccc}
\hline \multicolumn{1}{c}{ Variabel } & Wilks' Lambda & $\mathrm{F}$ & df1 & df2 & Sig. \\
\hline Letak Hutan & 0,916 & 20,565 & 1 & 225 & 0,000 \\
\hline Jarak Bupati & 0,992 & 1,865 & 1 & 225 & 0,173 \\
\hline Bahan Bakar Memasak & 0,901 & 24,641 & 1 & 225 & 0,000 \\
\hline Penghasilan Penduduk & 0,991 & 2,135 & 1 & 225 & 0,145 \\
\hline Kesehatan & 0,982 & 4,183 & 1 & 225 & 0,042 \\
\hline Jarak ke Kecamatan & 0,995 & 1,117 & 1 & 225 & 0,292 \\
\hline Persen PLN & 0,999 & 0,305 & 1 & 225 & 0,581 \\
\hline Pertokoan & 0,991 & 2,017 & 1 & 225 & 0,157 \\
\hline Pasar & 1,000 & 0,072 & 1 & 225 & 0,789 \\
\hline SMP & 0,984 & 3,649 & 1 & 225 & 0,057 \\
\hline Penerangan & 0,958 & 9,831 & 1 & 225 & 0,002 \\
\hline Jalan & 0,999 & 0,284 & 1 & 225 & 0,595 \\
\hline Angkutan & 1,000 & 0,054 & 1 & 225 & 0,817 \\
\hline Gotong Royong & 0,995 & 1,123 & 1 & 225 & 0,290 \\
\hline KUD & 0,993 & 1,567 & 1 & 225 & 0,212 \\
\hline Kredit & 1,000 & 0,004 & 1 & 225 & 0,948 \\
\hline Bank & 0,998 & 0,442 & 1 & 225 & 0,507 \\
\hline
\end{tabular}

Untuk pembentukan fungsi diskriminan, terlebih dahulu perlu melakukan uji keberadaan fungsi diskriminan untuk mengetahui apakah kebermanfaatan fungsi tersebut dalam membedakan kedua kelompok yang ada. Dari hasil uji tersebut, didapatkanlah nilai $p$ value sebesar 0,000 ( $p$-value $<0,05)$ yang berarti fungsi diskriminan tersebut dapat digunakan untuk membedakan klasifikasi desa tertinggal dan tidak tertinggal.

Tabel 8. Hasil Fungsi Diskriminan

\begin{tabular}{lc}
\hline \multicolumn{1}{c}{ Variabel } & Konstanta \\
\hline Konstanta & $-2,561$ \\
\hline Letak Hutan & 1,353 \\
\hline Bahan Bakar Memasak & $-1,249$ \\
\hline Kesehatan & 0,154 \\
\hline Penerangan & 0,720 \\
\hline
\end{tabular}

Sehingga fungsi diskriminan yang terbentuk adalah sebagai berikut:

$\hat{Y}=-2,561+1,353$ Letak Hutan - 1,249Bahan Bakar Memasak + 0,154 Kesehatan + 0,720 Penerangan

(3)

Walupun fungsi diksriminan telah terbentu, perlu dilakukan uji $\mathrm{F}$ untuk mengukur jarak antara dua kelompok dengan $\mathrm{D}^{2}$ jarak Mahalanobis. Uji tersebut diperlukan untuk mengevaluasi variabel terpenting dalam model. Dari Tabel 10 terlihat bahwa dari keempat variabel yang signifikan, hanya ada tiga variabel yang masuk kedalam model. Adapaun variabel kesehatan dianggap tidak mampu membedakan kedua kelompok secara berarti.

Tabel 9. Variabel Entered/Removed

\begin{tabular}{|c|c|c|c|c|c|c|}
\hline \multirow[t]{3}{*}{ Step } & \multirow[t]{3}{*}{ Entered } & \multicolumn{5}{|c|}{ Min. D Squared } \\
\hline & & \multirow[t]{2}{*}{ Statistik } & \multicolumn{4}{|c|}{ Eksak F } \\
\hline & & & Statistik & $\mathrm{df1}$ & df2 & Sig. \\
\hline 1 & Bahan Bakar Memasak & 0,733 & 24,641 & 1 & 225 & 1,363E-006 \\
\hline
\end{tabular}




\begin{tabular}{lllllll}
\hline 2 & Letak Hutan & 1,103 & 18,444 & 2 & 224 & $3,845 \mathrm{E}-008$ \\
\hline 3 & Penerangan & 1,283 & 14,235 & 3 & 223 & $1,605 \mathrm{E}-008$ \\
\hline
\end{tabular}

Sehingga fungsi diskriminan final yang dihasilkan adalah sebagai berikut: $\widehat{Y}=-2,466+1,339$ Letak Hutan - 1,336 Bahan Bakar Memasak + 0,792 Penerangan (4)

Hasil pengelompokan menurut fungsi diskriminan dari persamaan tersebut menunjukkan bahwa dari 227 desa sampel, dimana sebanyak 13 (5,73 persen) desa tergolong tertinggal dan $214(94,27$ persen) desa tergolong tidak tertinggal dengan hit ratio $=84,14$ persen dan APER = 15,86 persen.

Tabel 10. Hasil Klasifikasi dengan Metode Stepwise

\begin{tabular}{clccc}
\hline & & \multicolumn{2}{c}{$\begin{array}{c}\text { Prediksi Pengelompokan } \\
\text { menurut Fungsi Diskriminan }\end{array}$} & \\
\cline { 2 - 4 } & & Tertinggal & Tidak Tertinggal & Total \\
\hline \multirow{2}{*}{$\begin{array}{c}\text { Pengelompokan } \\
\text { Awal }\end{array}$} & Tertinggal & 9 & 32 & 41 \\
\cline { 2 - 4 } & Tidak Tertinggal & 4 & 182 & 186 \\
\hline \multicolumn{2}{c}{ Total } & 13 & 214 & 227 \\
\hline
\end{tabular}

Dari hasil pengolahan tersebut diperoleh dua fungsi diskriminanan, yaitu persamaan (3) dan persamaan (4). Persamaan (3) menghasilkan hit ratio $=85,0$ persen, sedangkan persamaan (4) menghasilkan hit ratio $=84,14$ persen. Kedua persamaan tersebut tidak memiliki perbedaan hit ratio yang begitu berarrti. Selain itu dalam persamaan (4) menggunakan variabel pembeda yang lebih sedikit dibandingkan persamaan (3). Hal ini menjadikan persamaan (4) lebih efisien secara praktik ketika dilakukan ground check.

Penerapan hasil fungsi diskriminan ke populasi menunjukkan bahwa dari 7.809 desa, sebanyak 550 (7,04 persen) desa tergolong tertinggal dan sebanyak 7.259 (92,96 persen) desa tergolong tidak tertinggal. Ketepatan klasifikasi pada populasi tersebut sebesar 82,57 persen.

Tabel 11. Hasil Klasifikasi terhadap Populasi

\begin{tabular}{clccc}
\hline & & \multicolumn{2}{c}{$\begin{array}{c}\text { Prediksi Pengelompokan } \\
\text { menurut Fungsi Diskriminan }\end{array}$} & \\
\cline { 2 - 4 } & & Tertinggal & Tidak Tertinggal & Total \\
\hline \multirow{2}{*}{$\begin{array}{c}\text { Pengelompokan } \\
\text { Awal }\end{array}$} & Tertinggal & 298 & 1.109 & 1.407 \\
\cline { 2 - 4 } & Tidak Tertinggal & 252 & 6.150 & 6.402 \\
\hline \multicolumn{2}{c}{ Total } & 550 & 7.259 & 7.809 \\
\hline
\end{tabular}

Dari hasil tersebut juga dapat dilakukan komparasi, bahwa klasifikasi wilayah tertinggal menggunakan hasil penelitian ini menunjukkan bahwa persentase desa tertinggal lebih tinggi dibandingkan persentase menurut IPD. Tingginya persentase tersebut memperkecil kontras kesimpulan jumlah persentase desa tertingal dan persentase jumlah penduduk miskin yang semakin mengecil yaitu terdapat diskrepansi statistik 7,42 persen.

\section{KESIMPULAN}

\section{Simpulan}

Dari hasil kajian tersebut dapat diperoleh kesimpulan bahwa menurut pendekatan pengelolaan lingkungan terdapat perbedaan antara kelompok desa tertinggal dan tidak tertinggal. Variabel yang signifikan membedakan status desa tersebut adalah letak desa terhadap hutan, penerangan jalan, bahan bakar memasak, dan fasilitas kesehatan. Adapun variabel fasilitas kesehatan tidak cukup penting dalam membedakan status desa tertinggal. Oleh karena itu, fungsi diskriminan yang terbentuk adalah $\hat{Y}=-2,466+1,339$ Letak Hutan $-1,336$ 
Bahan Bakar Memasak + 0,792 Penerangan. Fungsi diskriminan tersebut mampu memprediksi pengelompokan desa tertinggal dan desa tidak tertinggal secara tepat sebesar 84,14 persen dan hanya 15,86 persen yang mengalami misklasifikasi. Hasil klasifikasi menurut fungsi diskriminan ini juga menunjukkan hasil yang berbeda dibandingkan dengan klasifikasi menurut IPD.

Implikasi

Berdasarkan hasil penelitian tersebut, implikasi dari penelitian ini yaitu: (1) memberikan masukan kepada pemerintah untuk memberikan perhatian lebih kepada desa-desa yang tertinggal, (2) memberikan pandangan bahwa pembangunan disektor infrastruktur masih cukup penting sebagai upaya memajukan suatu wilayah agar terbebas dari ketertinggalan.

\section{Saran}

Perbedaan hasil klasifikasi desa antara penggunaan IPD dan fungsi diskriminan dalam penelitian ini perlu dikaji lebih lanjut. Kajian yang direkomendasikan untuk penelitian selanjutnya yaitu tentang komparasi penggunaan model klasifikasi dengan pendekatan statistik multivariat lainnya seperti: clustering, nearest neighbor classification, dan classification and regression tree.

\section{DAFTAR PUSTAKA}

Badan Pengkajian dan Penerapan Teknologi. (2002). Pengembangan Wilayah dan Otonomi Daerah: Kajian Konsep dan Pengembangan. Jakarta: Pusat Pengkajian Kebijakan Teknologi Pengembangan Wilayah.

Badan Pusat Statistik. (2015). Indeks Pembangunan Desa 2014. Jakarta: Badan Pusat Statistik.

Badan Pusat Statistik. (2019, Juli 19). Persentase Penduduk Miskin Menurut Provinsi 2007 - 2019. Retrieved from Badan Pusat https://www.bps.go.id/dynamictable/2016/08/18/1219/persentase-pendudukmiskin-menurut-provinsi-2007---2019.html

Badan Pusat Statistik Kabupaten Pekalongan. (2019, Februari 1). Ketimpangan Pembangunan di Jawa Tengah 2017. Retrieved from Badan Pusat Statistik Kabupaten Pekalongan: https://pekalongankab.bps.go.id/news/2018/04/05/17/ketimpangan-pembangunandi-jawa-tengah-2017.html

Bappenas. (2014). Rencana Pembangunan Jangka Menengah Nasional 2015-2019. Jakarta: Badan Perencanaan Pembangunan Nasional.

Chalid, P. (2015). Teori dan Isu Pembangunan. Tangerang: Universitas Terbuka.

Fauzia, M. (2019, Mei 17). Pindah Ibukota Jadi Solusi Ekonomi RI yang Jawa Sentris? Retrieved from Kompas: https://money.kompas.com/read/2019/05/17/093200826/pindahibukota-jadi-solusi-ekonomi-ri-yang-jawa-sentris-?page=all

Gujarati, D. N., \& Porter, D. C. (2008). Basic Econometrics (5th ed.). New York: Mc Graw Hill.

Johnson, R. A., \& Wichern, D. W. (2007). Applied Multivariate Statistical Analysis. New Jersey: Pearson Prentice Hall International.

Kementerian Desa, Pembangunan Daerah Tertinggal da. (2016). Petunjuk Pelaksanaan Identifikasi Masalah-Masalah Ketertinggalan Kabupate Daerah Tertinggal. Jakarta: Kementerian Desa, Pembangunan Daerah Tertinggal dan Transmigrasi.

Mubyarto. (1994). Pengantar Ekonomi Pertanian. Yogyakarta: LP3ES.

Muhtar, \& dkk. (2011). Masyarakat Desa Tertinggal: Kebutuhan, Permasalahan, Aset, dan Konsep Model Pemberdayaannya. Jurnal Penelitian dan Pengembangan Kesejahteraan Sosial, 16(1), 17-34.

Pane, R. A., Topowijono, \& Husaini, A. (2015). Analisis Diskriminan untuk Memprediksi Kebangkrutan Perusahaan: Studi pada Perusahaan Manufaktur yang Terdaftar di Bursa Efek Indonesia Tahun 2011-2013. Jurnal Administrasi Bisnis, 27(2), 1-8. 
Ratnadila, N. S. (2018). Perencanaan Skenario untuk Pembangunan Desa Tertinggal: Sebuah Telaah Kritis. Jurnal Penyuluhan Perikanan dan Kelautan, 12(2), 111-128.

Rosalina, S. S. (2008). Analisis Faktor-Faktor Penentu Ketertinggalan Wilayah KBI dan KTI. Bogor: Institut Pertanian Bogor.

Sumodinigrat, G. (2007). Pemberdayaan Sosial: Kajian Ringkas tentang Pembangunan Manusia Indonesia. Jakarta: PT Kompas Media Nusantara.

Supranto, J. (2004). Analisis Multivariabel: Arti dan Interpretasi. Jakarta: PT Rineka Cipta.

Tikson, D. T. (2005). Indikator-Indikator Pembangunan Ekonomi. Semarang: Badan Penerbit Universitas Diponegoro.

Trinanda, R. A., \& Santoso, E. B. (2013). Penentuan Faktor-Faktor yang Mempengaruhi Ketertinggalan Kawasan Pemekasan. Jurnal Teknik Pomits, 2(2). 